\title{
Introduction to the IJELLO Special Series of Chais Conference 2012 Best Papers
}

\author{
Nitza Geri \\ The Open University \\ of Israel, Raanana, \\ Israel \\ nitzage@openu.ac.il
}

Yoram M. Kalman

The Open University of Israel, Raanana, Israel

yoramka@openu.ac.il

\author{
Avner Caspi \\ The Open University \\ of Israel, Raanana, \\ Israel \\ avnerca@openu.ac.il
}

\author{
Sigal Eden \\ Bar-Ilan University \\ Ramat Gan \\ Israel \\ ueden@upp.co.il \\ Yoram Eshet-Alkalai \\ The Open University \\ of Israel, Raanana, \\ Israel
}

yoavya@openu.ac.il

\begin{abstract}
This is the fourth issue of Interdisciplinary Journal of E-Learning and Learning Objects (IJELLO) special series that includes a selection of best papers presented at Chais Conference on Instructional Technologies Research 2012: Learning in the Technological Era. The $7^{\text {th }}$ Chais conference was held at The Open University of Israel, Raanana, Israel, on February 15-16, 2012, and was organized by its Research Center for Innovation in Learning Technologies.

This preface presents the mission and activities of the Research Center for Innovation in Learning Technologies at the Open University of Israel. It describes the objectives and themes of the Chais Conference 2012, explains its synergies with IJELLO and the Informing Science Institute, and introduces the papers included in this special selection.
\end{abstract}

Keywords: instructional technologies, e-learning, technology integration in education, diffusion of innovation, human-computer interaction.

\section{Introduction}

Innovative instructional and learning technologies are among the major forces that can improve

Material published as part of this publication, either on-line or in print, is copyrighted by the Informing Science Institute. Permission to make digital or paper copy of part or all of these works for personal or classroom use is granted without fee provided that the copies are not made or distributed for profit or commercial advantage AND that copies 1) bear this notice in full and 2) give the full citation on the first page. It is permissible to abstract these works so long as credit is given. To copy in all other cases or to republish or to post on a server or to redistribute to lists requires specific permission and payment of a fee. Contact Publisher@,InformingScience.org to request redistribution permission. knowledge dissemination, education, life-long learning, on-the job training, and subsequently welfare in the information era. The Open University of Israel (OUI) is based on distance and blended learning and thus is committed to the ongoing examination and improvement of its teaching quality through the integration of innovative learning and instructional technologies. The Research Center for Innovation in 
Learning Technologies functions as the research arm of the Open University for exploring emerging technologies and developing models and strategies for their integration in teaching and learning. The main objective of the Center is to promote research related to the enhancement of instruction, using innovative learning technologies. The Center consists of a consortium of about forty faculty members from the various OUI departments. The Center conducts a wide range of ongoing academic activities such as symposia, workshops, conferences, and research seminars.

The following are some of the fields of research in which the Research Center for Innovation in Learning Technologies is engaged:

- The theoretical foundations of learning, instructional technology and distance education.

- Integration of innovative information and communication technologies into educational systems.

- Defining and characterizing the variables necessary for developing flexible and adaptive technology-enhanced instructional strategies that accommodate students' individual needs.

- Studying the pedagogical and cognitive contributions of emerging technologies to teaching and learning.

"Learning in the Technological Era" is a series of annual national research conferences on learning technologies initiated in 2006 by the Chais Research Center in collaboration with EDEN, The European Distance and E-Learning Network. The Research Center for Innovation in Learning Technologies is committed to continuing this important research activity, under the name of Chais conference, which commemorates the contribution of the late Stanley Chais, who funded the establishment of the Chais Center. The Chais conference contributes to the formation of a community of Israeli researchers in the field of instructional technologies and to the positioning of the Open University of Israel as a leading organization in the study and implementation of learning technologies. About 500 researchers from most universities and academic colleges in Israel and from many organizations and Information Technology (IT) companies participate in the conference each year.

The purpose of this IJELLO special series of Chais conference best papers is to enhance the international impact of the Chais conference by distributing high quality papers from the National conference to a worldwide audience. The Informing Science Institute (ISI) is a natural partner for this mission because it draws together researchers and practitioners of information technologies, who seek effective ways to inform clients about sharing their knowledge with others (http://www.informingscience.org/). The informing science transdiscipline studies the informing process, defined as providing a specific clientele with information in a form, format, and schedule that maximizes its effectiveness (Cohen, 1999, 2009; Gill \& Cohen, 2009). Instructional technologies are a certain type of information technologies, which aim at providing students and other learners with information and tools to enhance their learning. Within the ISI journals, the Interdisciplinary Journal of E-Learning and Learning Objects publishes high quality articles on theory, practice, innovation, and research that cover all aspects of E-learning and Learning Objects (http://www.ijello.org).

The first selection in this series was published three years ago and included 13 papers, which dealt with various aspects of technology integration in teaching and learning, collaborative learning environments, quality of mobile learning, motivation for technology use, and more (EshetAlkalai, Caspi, Eden, Geri, \& Yair, 2009). The second selection included nine of the best papers presented at Chais conference 2010, on the topics of integration of technology in education systems, diffusion of innovation in learning environments, mobile culture, school versus home learning, collaborative learning, and social aspects (Eshet-Alkalai, Caspi, Eden, Geri, \& Yair, 2010). The third selection of Chais conference 2011 best papers, which was published last year, empha- 
sized the role of teachers in integrating innovative instructional technologies (Geri, Yair, Caspi, Eden, \& Eshet-Alkalai, 2011).

This issue includes eight selected best papers of the 2012 Chais conference that represent the following aspects of learning technologies implementation and use: innovative technologies for teaching and learning, instruction in technological environments, perceptions of online teaching and learning, cognitive aspects of learning in technological environments, simulations in instruction and learning. This year, for the first time, we introduced the Chais conference best student paper award. Twenty papers that were presented in the Chais 2012 Conference were candidates for the Best Student Paper Award. This issue includes the Chais 2012 best student paper, as well as three other finalists.

\section{Chais Conference 2012 Best Papers}

Out of 85 papers that were submitted to the 2012 Chais conference and underwent a blind peerreview process, 40 papers and 30 posters were accepted for presentation at the conference and were included in the conference's proceedings volume (Eshet-Alkalai et al., 2012). This fourth selection of the IJELLO Special Series of Chais Conference Best Papers includes eight of the most outstanding Chais Conference 2012 papers, which were expanded and modified for publication in IJELLO, and have undergone a full review process by the IJELLO Editors and reviewers.

The first paper by Ina Blau and Yehuda Peled ("Teachers' openness to change and attitudes towards ICT: Comparison of laptop per teacher and laptop per student programs") focused on teachers. Blau and Peled examined how openness to change and attitudes towards information and communication technologies (ICT) implementation of Israeli middle school teachers influence the teachers' online communication and their online information search patterns. They compared three groups: the first group worked in one-to-one laptop classrooms, the second one received a laptop from the state for pedagogical use, and the last group did not use technology for teaching. Their findings indicate that teachers in the one-to-one program showed higher level of awareness of the time invested in preparing digital learning materials, which may in turn a barrier to technology adoption. Therefore, Blau and Peled suggest that it is important to develop suitable digital content that can be adapted by teachers. Furthermore, according to their findings, teachers who received laptops reported higher levels of openness to professional changes, to online communication, and online information search for both personal and professional purposes. Hence, Blau and Peled suggest that providing teachers with personal devices for pedagogical use and online communication is an important enabler of such changes.

The second paper by Ornit Spektor-Levy and Yael Granot Gilat ("The impact of learning with laptops in 1:1 classes on the development of learning skills and information literacy among middle school students") was a finalist for the best student (Yael Granot Gilat) paper award of the Chais 2012 conference. Their study examined the impact of a one-to-one program on developing student skills, a demand placed upon schools, as 21 st century competencies. Their unique research tool consisted of a complex, computer-based learning task. Completion of the task required implementation of skills such as information retrieval, information evaluation, reading comprehension, information processing and representation, and knowledge presentation. Their findings indicated that students of one to one classes performed significantly better than students of the comparison group that did not use ICT. Spektor-Levy and Granot Gilat's findings demonstrate the positive effect of learning with personal laptops and routinely available ICT on student achievements and competencies.

Yair Levy and Michelle M. Ramim ("A study of online exams procrastination using data analytics techniques") have used a novel research methodology, data analytics, for addressing the issue of procrastination, which is one of the main challenges of online learning. Research related 
Introduction to the IJELLO Special Series of Chais Conference 2012 Best Papers

to the general phenomenon of procrastination is well established; however, studies assessing procrastination in the context of online learning activities are still scarce. Levy and Ramim's exploratory study analyzed student performance in online exams over a period of five terms in an academic institution in the southeastern United States. Their results indicated that over half of the students tended to procrastinate and that those who procrastinated appeared to perform significantly poorer than those who staged their work. Their paper identifies some other interesting trends and suggests directions for further study.

The next paper, by Rania Hussein-Farraj, Miri Barak, and Yehudit Judy Dori ("Lifelong learning at the Technion: Graduate students' perceptions of and experiences in distance learning") was a finalist for the best student (Rania Hussein-Farraj) paper award of the Chais 2012 conference. Their study investigated the role of e-learning as an enabler for life-long learning. They compared student perceptions and experiences of distance learning (DL) students and traditional on-campus students. A distinctive aspect of their study was the sample, which included science and engineering graduate students. It seems that this particular population may gain from lifelong DL opportunities. Hussein-Farraj, Barak, and Dori's main findings indicated that the DL students asserted positive perceptions of their learning experiences, and female DL students were more confident about their ability to communicate with their classmates and lecturers. Their study also included content analysis, which revealed four main categories related to lifelong learning via DL: cognitive and professional skills, affective learning, social interactions, and resource management. Such studies may help improve online courses in higher education.

The next four papers deal with various uses of technology for learning by different age groups, starting with kindergarten, continuing with junior high school, high school, and finally, college students.

Asi Kuperman and David Mioduser's paper ("Kindergarten children's perceptions of 'anthropomorphic artifacts' with adaptive behavior") received the best student (Asi Kuperman) paper award of the Chais 2012 conference. Kuperman and Mioduser's study investigated children's stance towards behaving artifacts. Specifically, they checked whether children perceived these artifacts as psychological or engineering entities. They analyzed children's explanations and examined their use of anthropomorphic or technological language. Their findings, which are in contrast with prior studies, revealed that children's engagement, shown by their behavior, in constructing the "anthropomorphic artifacts" promoted the use of technological language and indicated the early development of a technological stance. The implications of Kuperman and Mioduser's study may promote effective development of technology-related learning tasks for kindergarten children.

Anat Cohen and Galit Duchan's paper ("The usage characteristics of Twitter in the learning process") was a finalist for the best student (Galit Duchan) paper award of the Chais 2012 conference. They examined a class of ninth graders that used Twitter, along with their teacher, as an afterschool teaching-supporting tool for traditional face-to-face (F2F) learning. The data were analyzed by decoding tweets, grouping tweets into various pedagogical and social uses, and exploring the technical Twitter related difficulties. Cohen and Duchan's results indicated that Twitter was mainly used for pedagogical uses, as answers to homework questions, and as comments to intriguing issues brought up throughout the lessons. Furthermore, the use of Twitter assisted in avoiding time-consuming difficulties in F2F learning and demonstrated its potential effectiveness as a learning tool.

Moshe Leiba, Ruth Zuzovsky, David Mioduser, Yehuda Benayahu, and Rafi Nachmias ("Learning about ecological systems by constructing qualitative models with DynaLearn") investigated qualitative models. Their paper examined an innovative approach to science education using an interactive learning environment that supports learners in expressing and simulating conceptual knowledge by building qualitative models in ecology. The learning environment and tools, which 
were used in their study, were being developed as part of the DynaLearn qualitative modeling research project, funded by the European Union's 7th framework programme and carried by a consortium of eight participant universities. Their main findings indicated that, from a systems thinking perspective, the modeling activity affected student perception of systems and improved its presentation.

Ronen Hammer, Miky Ronen, and Dan Kohen-Vacs ("On-line project-based peer assessed competitions as an instructional strategy in higher education") addressed the challenging issue of peer assessments. Their paper analyzed online peer assessed competitions of team projects in several undergraduate courses. The findings of Hammer, Ronen, and Kohen-Vacs indicated high correlations between the instructor's grading and those of the students. Moreover, peer assessments seemed to provide candid, rich, and multiple-perspective feedback. Students perceived peer assessments as valid regardless of the grade they received; most of them reacted favorably to the challenge of exposing their artifacts to peer judgments and believed that because of this process they invested more effort and thus improved the quality of their own artifacts.

The above papers represent the main themes of the Chais 2012 conference. Other themes that were presented at the conference but were not covered in this special selection included ethical issues in learning and teaching; communities of knowledge; mobile learning; technology in the service of people with special needs; virtual reality applications for learning; and digital games.

\section{Conclusion and Acknowledgements}

This fourth issue of IJELLO's special selection of Chais conference best papers presents some of the current major issues and trends in learning technology studies. We hope these papers will be of interest to the readers and will encourage future innovative and synergetic instructional technologies research.

We would like to express our deep thankfulness to Janice Whatley, the Editor-in-Chief of the Interdisciplinary Journal of E-Learning and Learning Objects, for her wholehearted support and for conducting this editorial effort. On behalf of the authors, we also thank Janice Whatley for her constructive guidance.

We acknowledge our continuing gratitude to Eli Cohen and Betty Boyd of the Informing Science Institute for enabling the production of this special series. Special thanks to Betty Boyd for the publishing work and for helping the authors with the presentation of their work.

Thanks to all the contributing authors and reviewers for their excellent work. Finally, we would like to thank the community of Israeli instructional technologies researchers and practitioners for participating in Chais conferences and contributing to the development of this important field.

\section{References}

Cohen, E. (1999). Reconceptualizing information systems as a field of the transdiscipline informing science: From ugly duckling to swan. Journal of Computing and Information Technology, 7(3), 213-219.

Cohen, E. (2009). A philosophy of informing science. Informing Science: the International Journal of an Emerging Transdiscipline, 12, 1-15. Retrieved from http://inform.nu/Articles/Vol12/ISJv12p001015Cohen399.pdf

Eshet-Alkalai, Y., Caspi, A., Eden, S., Geri, N., \& Yair, Y. (2009). Introduction to the IJELLO special series of Chais Conference 2009 best papers. Interdisciplinary Journal of E-Learning and Learning Objects, 5, 181-186. Available at: http://ijello.org/Volume5/IJELLOv5p181-186ChaisPreface.pdf

Eshet-Alkalai, Y., Caspi, A., Eden, S., Geri, N., \& Yair, Y. (2010). Challenges of integrating technologies for learning: Introduction to the IJELLO special series of Chais Conference 2010 best papers. Interdis- 
ciplinary Journal of E-Learning and Learning Objects, 6, 239-244. Available at: http://www.ijello.org/Volume6/IJELLOv6p239-244Intro.pdf

Eshet-Alkalai, Y., Caspi, A., Eden, S., Geri, N., Yair, Y., \& Kalman, Y. (Eds.) (2012). Proceedings of the Chais conference on instructional technologies research 2012: Learning in the technological era. Raanana: The Open University of Israel.

Geri, N., Yair, Y., Caspi, A., Eden, S., \& Eshet-Alkalai, Y. (2011). Learning and teaching in the technological era: Introduction to the IJELLO special series of Chais Conference 2011 best papers. Interdisciplinary Journal of E-Learning and Learning Objects, 7, 205-211. Available at: http://www.ijello.org/Volume7/IJELLOv7p205-211ChaisIntro.pdf

Gill, T. G., \& Cohen, E. (Eds.). (2009). Foundations of informing science, 1999-2008. Santa Rosa, CA: Informing Sciences Press.

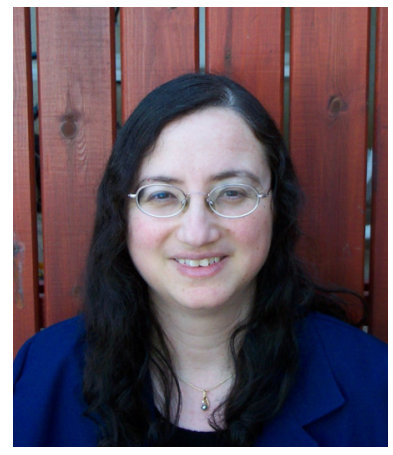

\section{Biographies}

Nitza Geri is a faculty member at the Open University of Israel, Department of Management and Economics, and Head of the Research Center for Innovation in Learning Technologies. She holds a B.A. in Accounting and Economics, an M.Sc. in Management Sciences and a Ph.D. in Technology and Information Systems Management from TelAviv University. Nitza is a CPA (Israel) and prior to her academic career she had over 12 years of business experience. Her research interests and publications focus on various aspects of the value of information, and information systems adoption and implementation, including strategic information systems, e-business, economics of information goods, attention economy, value creation and the Theory of Constraints, managerial aspects of e-learning systems adoption and use. Personal site: http://www.openu.ac.il/Personal_sites/nitza-geri.html

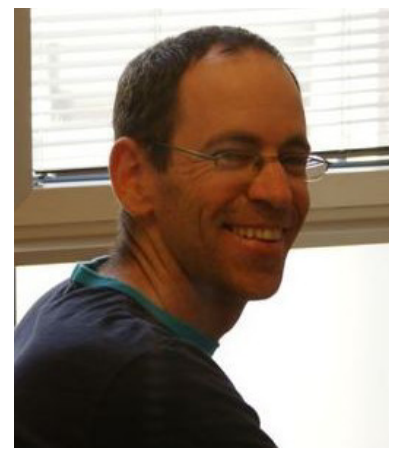

Avner Caspi is a faculty member at the Open University of Israel, Department of Education \& Psychology. He holds a B.A. in Behavioral Sciences (Tel-Aviv Yaffo Academic College), and Ph.D. in Cognitive Psychology (Tel Aviv University). His major research and publications interests focus on social aspects of communication technologies, mainly in the area of learning and instruction. Personal site: http://www.openu.ac.il/Personal_sites/avner-caspi.html

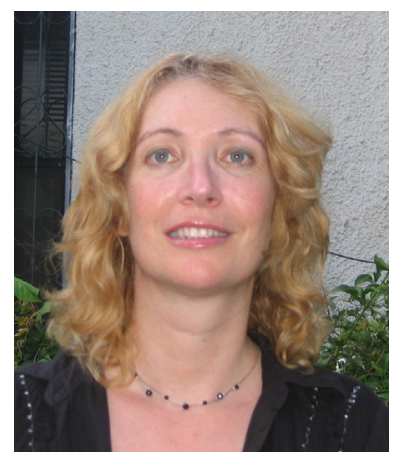

Sigal Eden is a lecturer at Bar Ilan University, School of Education and formerly a fellow researcher and a member of the Research Center for Innovation in Learning Technologies, the Open University of Israel. She holds a B.A. in Education for Students with Hearing Impairment from Tel-Aviv University, an M.A. and Ph.D. in Educational Technologies from Bar-Ilan University. Her research interests and publications focus on various aspects of working with digital environments, especially the enhancement of cognitive and linguistic aspects among people with special needs. Personal site: http://www.openu.ac.il/research center_eng/Sigal_Eden card E.html 

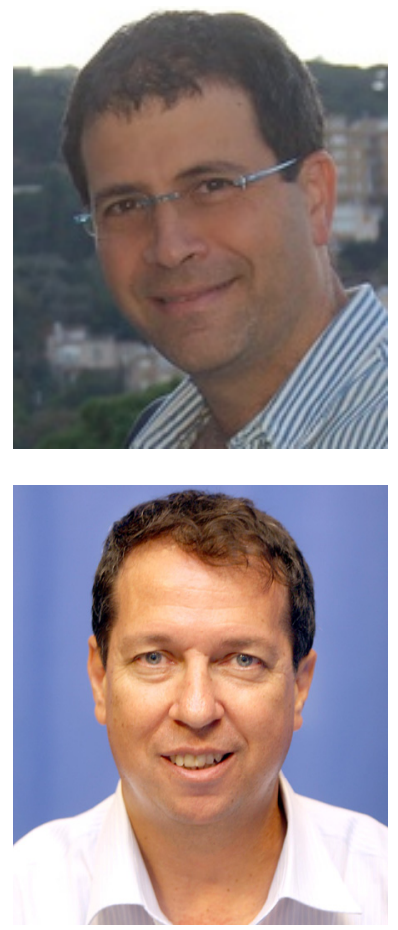

Yoav Yair is Dean of Development and Educational Technology at the Open University of Israel. He is a faculty member at the Open University, Department of Life and Natural Sciences. He is an expert on educational technology, having worked as software designer and educational program developer at the Centre for Educational Technology (CET) in Tel-Aviv for 15 years. His main interests in this field are scientific visualization and desktop virtual reality. He also wrote 4 textbooks for the K-12 Israeli education system and was a chief software designer of several educational software and websites. At the Open University of Israel, in the years 2004-2009, Prof. Yair headed the Center for Technology in Distance Education (SHOAM), tasked with developing, testing, disseminating and evaluating learning technologies for usage in distance education. In this capacity he was responsible for introducing new technologies into the Open University, with emphasis on the academic usage of the OPUS Hebrew-based learning management system, of video broadcasts and synchronous voice-over-IP systems, as well as collaborative tools such as Wikis. Prof. Yair leads the Open Courseware project at the Open University of Israel, with a new initiative to open complete e-books and audio-books on-line for free usage by the general public. Prof. Yair published numerous papers in atmospheric sciences and on the usage of technology in science and distance education. He now leads new projects in mobile e-books for academic courses. Prof. Yair is an atmospheric and space physicist and leads a research team for studying thunderstorms, lightning and their effects on the atmosphere. Another field of research is science education with emphasis on Astronomy and the Earth Sciences. Personal site: http://www.openu.ac.il/Personal sites/yoav-yair.html

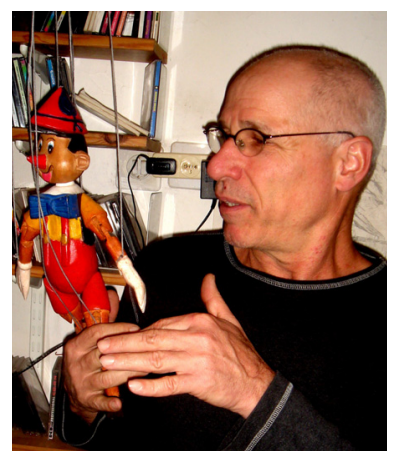

Yoram Eshet-Alkalay is a faculty member at the Open University of Israel, Department of Education \& Psychology. He is the Coordinator of the M.A. program in educational technology, and the former Head of the Research Center for Innovation in Learning Technologies in the Open University. He holds a B.A. in Archeology (Hebrew University), M.Sc. in Geology (Hebrew University) and Ph.D. in Earth \& Environmental Sciences (City University of NY). For a decade, he was the Head of the Instructional Design Program in the Tel Hai Academic College, and a senior researcher in the Geological Survey of Israel. He has 15 years experience in developing technology-based instructional solutions for educational systems in Israel and the USA. In this capacity, he was involved in the design of hundreds of simulations, databases, tutorials and large-scale curriculum integration projects. His major research and publications interests focus on cognitive aspects of working with digital technologies, digital games and design principles of computerbased learning environments. Personal site: http://www.openu.ac.il/Personal_sites/yorameshet.html 